\title{
INSURANCE MARKET MATURITY: A COMPARATIVE STUDY IN POLAND AND LITHUANIA
}

\author{
Tomasz Bernat ${ }^{1}$, Dainora Grundey ${ }^{2 *}$ \\ ${ }^{1}$ Dept of Microeconomics, Faculty of Economics and Management, University of Szczecin, \\ ul. Mickewicza 64, Room 429, Szczecin, Poland.E-mail: bernatom@o2.pl \\ ${ }^{2}$ Dept of Business Economics and Management, Kaunas Faculty of Humanities, Vilnius University, \\ Muitinés g. 8, LT-44280 Kaunas, Lithuania.E-mail: dainora.grundey@vukhf.lt
}

\author{
Received 11 June 2007; accepted 10 September 2007
}

\begin{abstract}
Market economy, functioning in most countries of the world, is built of markets operating within it. Overviewing its origin historically, we should analyse the stages of its development or transformations, which influenced its present form. The markets in the economies are more or less free and the economies are more or less market, depending on the state's policy, the citizens' attitudes, the legal system etc [1, p. 19-20]. These factors form the functioning of individual markets with all the elements of their effects. The aim of the paper is the analysis of insurance markets in Poland and Lithuania in reference to EU-15. It is subordinated to a research hypothesis, which states that insurance markets of the surveyed countries (Poland and Lithuania), which have experienced system transformations, are further formed according to the model of the developed-mature markets, which are functioning in market economies for many years.
\end{abstract}

Keywords: insurance market, market maturity, competition, Poland, Lithuania.

\section{Introduction}

Markets are processes of exchange between sellers and buyers. These processes are influenced by numerous factors. They make a market function better - satisfying the basic needs of all its participants, or worse, when one of the parties has advantage or when not all of the basic needs can be satisfied. Assessment of the market in this regard should allow drawing conclusions of possible reasons of such an effect.

The problem is obviously the point of reference that allows stating what is better or worse, ie the demand of creating a standard model.

Market analysis should apply to time characteristics: short- and long-term functioning. The division is connected with the possibility of influencing the market and its components to, eg, limit unfavourable phenomena. There is usually no possibility to make significant changes in demand and supply in a short period. Changes in a long period, however, look different. The factors operating shortterm may influence the functioning of the whole market body in a long period. Such a signal could be price increase on a market caused by demand increase that will create the entrepreneurs' larger interest in the market long-term, because of the possible profits. Also the mechanism of self-

\footnotetext{
* Corresponding author
}

regulation, aiming at establishing the market balance, functions differently for a long term.

Therefore it should be considered whether markets could be stable in the long term. What does market maturity mean in this regard?

Nowadays the economy and business world is the one of competition and social agreements. The main engines of global changes are liberalisation, privatisation and deregulation of economies. It makes nobody and nothing await the changes to pass by. On the other hand, the impact of global economic subjects and building over-national political-economic groups (Triada) make similar solutions and players occur all over the world (an example could be global brands such as Microsoft, IBM, Intel, Coca Cola, Ford, Procter\&Gamble, Shell, Nike, Allianz, AIG etc). For consumers they appear in three main dimensions: assurance of high quality, globalisation myth and social responsibility [2].

Globalisation in this regard contributes to integration of various, and independent at the start, markets in various countries into cross-national world markets. It manifests in growth of correlation of markets and production in most countries [3].

Functioning of global enterprises makes the methods of corporation management and creation of own markets transfer to other countries. This, successively, creates the 
necessity of introducing new solutions, similar, however, to the global competitors, by the subjects in the countries the global players have already entered. In effect, it can stabilise the market because of the participation of large and long-term enterprises.

Long-term stabilisation of market may be considered concerning economic perfect competition theory. According to its premises, enterprises gain zero economic profits in a long period. It means that all the subjects will function on similar profit level as the measure of their effectiveness. Simultaneously, with respect to generally known premises of the model, it could be assumed that all the subjects should function and be conducted similarly. In this respect, it may be the basis of estimating the market maturity. Therefore a market reaches its maturity when the enterprises functioning there for a long-term are conducted in a similar way. This way is a reflection of conditions ruling such a market. It should also be assumed that there exists a free economy, meaning that everyone has equal chances of development and making decisions, and that there is no significant supporting or limiting of a particular enterprise by the state. The effects will depend exclusively on the decisions made by the subjects according to the rules of the market.

Perfect competition model is a virtual reflection of the perfect solution. In real world, there function imperfect competitive forms of markets, with a larger or smaller level of competition. Enterprises in a long period are independent in their choice of both manufacturing factors and legalorganisational solutions. It will depend on carrying stated goals into effect - maximisation of profits, the enterprise value etc.

What concerns a long term in imperfect competition analysis, it also should be assumed that enterprises would aspire to gain maximum profits [4]. Depending on competition level (or, in other words, monopolisation), market will more or less unify, as far as profits, cost levels etc are concerned. In spite of the meaning of competition level itself, there are additional factors as well, such as the ability to use the effect of the scale of production, the level of market power, lobbing ability or market development rate. Market maturity in imperfectly competitive structures could be defined similarly to the perfect solution. However, in respect to inequality in market power occurring in practice, similarity of subjects must be of more relative character. It is difficult to compare a subject owning $80 \%$ of market shares to a small enterprise owning $5 \%$. The problem of stability and maturity is also a question of what market should be, that is what its structure should be like, how it should function under definite conditions of the country [5]. Long-term stability of such a market would therefore mean the stability of its structure, conduct and performance [6]. Therefore a mature market is the one, which, in the long-run, the product sales'structure and the sales' structure, measured in market shares and the market concentration indicator, does not change significantly, assuming there are no major changes in the business environment.

Obviously, the concepts of 'significantly' and 'major changes' are not clear and must be précised for the sake of the research included in the paper, what would be done in further part, with the EU-15 market as the reference.

The aim of the paper is the analysis of insurance markets in Poland and Lithuania in reference to EU-15. It is subordinated to a research hypothesis, which states that insurance markets of the countries, which have experienced a system transformation are formed by the model of the developed - mature markets, functioning under market economies for many years.

\section{Determinants of change in insurance markets}

Insurance market in the world is divided into numerous national markets. The largest and the most developed markets are based in the countries of high economic development level, as shown in Fig 1.

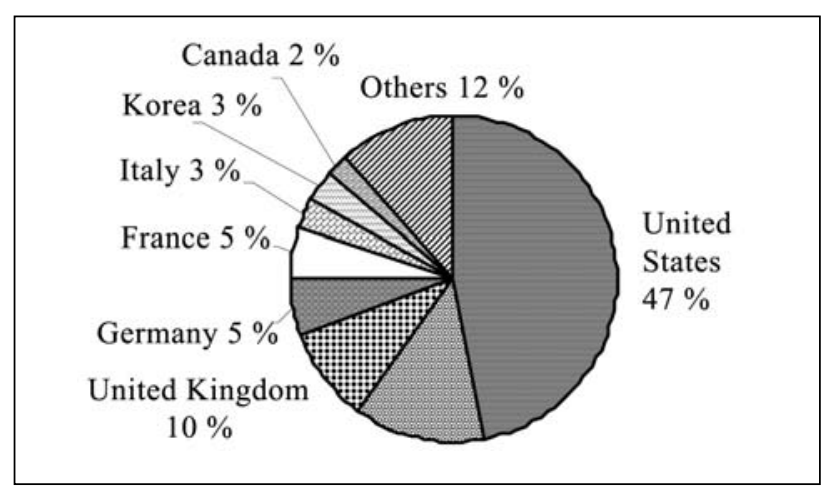

Source: own project based on [7]

Fig 1. Total market share of the OECD countries in insurance business in 2001

On the basis of Fig 1, it is clear that the USA has the largest market share among the analysed countries. The share of the European countries - EU-15, was in the research period of $31,14 \%$, which was the total set of gross premiums at the level of $\$ 767,756$ million. Therefore these markets could be recognised as the model for the developing countries not only with regard to the collected premiums (as it largely depends on the wealth of the country), but also to the factors shaping the global conditions of insurance market. The most significant determinants influencing the present form of financial markets in the world, in global reference [8, p. 33-39], are:

- financial inequalities between debt and capital ownership;

- legal deregulation occurring on the world markets connected with liberalisation and increasing competition;

- globalisation, including: new technologies, integration of financial markets and creating of over-national financial conglomeration (banks, insurance companies, trust investment and pension funds);

- technological processes linked to a larger and larger influence of the Internet on economic activities;

- shareholders' influence on enterprises' profitability; 
- aggregation of wealth in various funds - especially pension funds.

The mentioned above changes in the global scale are influencing, and they will cause the changes in particular countries and regions. It concerns all the financial markets, including the insurance ones. There could be highlighted the factors influencing functioning of these markets locally, especially meaningful in the analysis conducted in this paper. The determinants operating within the country, in reference to the structure of conduct and effect market, include:

- market deregulation, characterised largely by its demonopolisation, liberalisation and openness to competition, especially in the EU after the integration;

- a slowdown in the market growth resulting from a slowdown in the growth of the economy and convergence to the level of insurance penetration indicated by the level of national income [9, p. 213]).

Important factors of change are also generally understood conducts of buyers, shaping the size of demand for insurance services [10], as well as the state policy creating consumers' conducts by imposing obligatory insurance or establishing substitution product markets such as pension funds, social and psychological factors such as financial status and insurance consciousness level (and not only), as well as insurance companies' activities imposed by the rivals to, among the others: adjusting the products to the needs and expectations of the market, attention to the image and professionalism of all the insurance agents. Crucial are also [11] such features of consumers' behaviour as demands increase, loyalty decrease, growing meaning of the products practical use. Determinants that are able to influence insurance market development could be development and changes of substitution and complementary products (such as social insurance), legal alternations concerning insurance, tax encouragement or the entrance of education into the process of stimulating insurance consciousness (as indicated by Perenc [12]).

Some of important determinants, not mentioned above, are the transformational changes of economies. Together

Table 1. Indices of Gross Domestic Product in Poland and Lithuania, 1995-2003

\begin{tabular}{|l|c|c|c|c|c|}
\hline \multicolumn{1}{|c|}{ Year } & $\mathbf{1 9 9 5}$ & $\mathbf{2 0 0 0}$ & $\mathbf{2 0 0 1}$ & $\mathbf{2 0 0 2}$ & $\mathbf{2 0 0 3}$ \\
\hline Country & \multicolumn{5}{|c|}{ Previous year $=100$} \\
\hline Poland & 107 & 104,0 & 101,0 & 101,4 & 103,8 \\
\hline Lithuania & 103 & 103,9 & 106,4 & 106,8 & 109,0 \\
\hline
\end{tabular}

Source: [13]

Table 2. Gross Domestic Product in Poland and Lithuania, in 1990-2003, selected years, in million of USD

\begin{tabular}{|l|c|c|c|c|}
\hline $\begin{array}{c}\text { Year/ } \\
\text { Country }\end{array}$ & $\mathbf{1 9 9 0}$ & $\mathbf{1 9 9 5}$ & $\mathbf{2 0 0 0}$ & $\mathbf{2 0 0 3}$ \\
\hline Poland & & 127085 & 157585 & 232770 \\
\hline Lithuania & 13254 & 7089 & 10634 & 13972 \\
\hline
\end{tabular}

Source: [13] with political changes of the economies of the post-communist countries, also the markets have undergone transformation or reconstruction - towards marketing all the processes. It concerns also the insurance markets. The factor caused former monopolists square up against market competition and undergo the process of economic transformation from an enterprise run by the state to a subject functioning on the basis of economic effectiveness [5]. Since the 90s, these changes influenced largely Polish and Lithuanian insurance market. The direction of the transformation was generally known - marketing, however, there were changes heading towards the solutions known in the European Union countries (EU-15).

\section{Economic indicators in Poland and Lithuania}

Transformation changes occurring in the economies of the Baltic countries were reflected in fact in all their elements. They concerned mainly redirecting of the economic sphere into a market one, and the political sphere into a democratic one. Their effects could be assessed researching selected macroeconomic indicators. The basic measure is Gross Domestic Product. Its dynamics is presented in Table 1.

The growth of GDP rate, which could have been observed in the researched period, was larger in Lithuania than in Poland. Table 2 shows the level of GDP in Poland and Lithuania.

As Table 2 indicates, GDP is obviously higher in Poland than in Lithuania because of the country market. A more objective measure here is GDP per capita (Table 3).

In the period researched it was generally larger in Poland. Assessing the economic growth rate and the alternations of the mentioned indicators, however, it should be stated that Lithuanian economy develops faster.

The indicator closely connected to financial markets is inflation rate. Its values in selected years are in Table 4.

The development of the economies of Poland and Lithuania although visible, did not proceed at the same rate. Lithuania managed economy transformation and its effects

Table 3. Gross Domestic Product per capita in Poland and Lithuania, in 1995-2003, selected years, in USD

\begin{tabular}{|l|c|c|c|c|}
\hline $\begin{array}{c}\text { Year/ } \\
\text { Country }\end{array}$ & $\mathbf{1 9 9 5}$ & $\mathbf{2 0 0 0}$ & $\mathbf{2 0 0 1}$ & $\mathbf{2 0 0 3}$ \\
\hline Poland & 3293 & 4078 & 4746 & 6000 \\
\hline Lithuania & 1911 & 2874 & 3058 & 4020 \\
\hline
\end{tabular}

Source: [13]

Table 4. Inflation rate in Poland and Lithuania, in 1996-2003, selected years

\begin{tabular}{|l|c|c|c|c|}
\hline $\begin{array}{c}\text { Year } / \\
\text { Country }\end{array}$ & $\mathbf{1 9 9 6}$ & $\mathbf{2 0 0 0}$ & $\mathbf{2 0 0 2}$ & $\mathbf{2 0 0 3}$ \\
\hline Poland & $20 \%$ & $10 \%$ & $1,8 \%$ & $2,4 \%$ \\
\hline Lithuania & $25 \%$ & $1 \%$ & $0,4 \%$ & $1 \%$ \\
\hline
\end{tabular}

Source: [13] 
much better. It is indicated by both economic growth rate and the inflation rate. Poland exceeds Lithuania only in relative value of GDP per capita indicator, although with a larger economic development rate of Lithuania, the difference has been so far constantly decreasing.

\section{Insurance market, methodology and research findings}

Insurance markets analysis concerning their maturity should precede according to the following pattern: firstly, the scope of the analysis would be presented, then the effect for mature markets, which in the paper shall be represented by the insurance market of the old European Union. To eliminate short-term fluctuations there will be established an average value of the analysis subject. This data will be compared with the current effects of insurance markets in the researched countries. As a result, a short assessment of the mentioned markets will be presented.

The research will be conducted for the following values:

- 'density' and 'penetration' indicators;

- sectors of insurance market shares (life and non-life);

- structure of the premiums collected in particular sectors.

The basic measures of global insurance markets are 'den-

Table 5. Density and penetration indicators in EU (15) countries, in 1994-2001

\begin{tabular}{|l|c|c|c|c|c|c|c|c|}
\hline Year & $\mathbf{1 9 9 4}$ & $\mathbf{1 9 9 5}$ & $\mathbf{1 9 9 6}$ & $\mathbf{1 9 9 7}$ & $\mathbf{1 9 9 8}$ & $\mathbf{1 9 9 9}$ & $\mathbf{2 0 0 0}$ & $\mathbf{2 0 0 1}$ \\
\hline $\begin{array}{l}\text { Den- } \\
\text { sity }\end{array}$ & 1370 & 1582 & 1664 & 1628 & 1705 & 1858 & 1926 & 1851 \\
\hline $\begin{array}{l}\text { Penet- } \\
\text { ration }\end{array}$ & 6,9 & 6,97 & 7,22 & 7,53 & 7,65 & 8,18 & 9,22 & 9,13 \\
\hline
\end{tabular}

Source: [7]

Table 6. Density and penetration indicators in Poland and Lithuania, 2002

\begin{tabular}{|l|c|c|c|}
\hline \multicolumn{1}{|c|}{$\begin{array}{c}\text { Indicator/ } \\
\text { Country }\end{array}$} & Poland & Lithuania & $\begin{array}{c}\text { EU (15) } \\
\text { average }\end{array}$ \\
\hline Density & 144,5 & 57,9 & 1698 \\
\hline Penetration & 2,96 & 1,46 & 7,85 \\
\hline
\end{tabular}

Source: [14] and [7] sity' and 'penetration' indicators. They do calculate as:

- Density = Direct Gross Premium/Population

- Penetration $=$ Direct Gross Premium/GDP

These indicators for the EU-15 are presented in Table 5.

As the analysis of the data in the Table shows, both indicators were growing in the researched period. It proves a constant development of insurance market. The effects for both researched countries in 2002 are in Table 6.

As Table 6 indicates, insurance in Poland and Lithuania largely differ from the long-term indicator value. In both cases, there should be a significant increase of insurance market. It suggests that these markets are still in the development stage, ie are not as mature as the markets of the EU countries. The dynamics of the growth of these markets in the EU-15 countries is presented in Table 7.

As Table 7 indicates, market growth rate in the researched countries did not differ from the ones in the EU-15. In both countries, the rate was generally higher than in reference to the developed markets. While analysing the average values, it should be indicated that in the EU-15 the average value of market growth in $1994-2001$ was $4,6 \%$, in Poland at the same time $19,1 \%$, while in Lithuania in 1999-2003 14,9\%. The data indicate that the two markets can be regarded as fast growing ones. Thus they are not in this reference mature.

The next element of the analysis is market structure. Firstly, there will be presented the structure based on the division of insurance market into life and non-life sectors. Table 8 presents the structure of gross premiums in division into life and non-life sectors.

The data presented in Table 8 indicate that in the researched period there occurred a change of the market share of individual insurance sectors. Life sector has become dominant. Average values of the shares are 53,28\% for life, while $46,72 \%$ for non-life. In the countries researched, the indicators differ from average values, as shown in Table 9.

Table 8. Structure of premiums (life and non-life) in UE 15, in 1994-2001

\begin{tabular}{|l|c|c|c|c|c|c|c|c|}
\hline Year & $\mathbf{1 9 9 4}$ & $\mathbf{1 9 9 5}$ & $\mathbf{1 9 9 6}$ & $\mathbf{1 9 9 7}$ & $\mathbf{1 9 9 8}$ & $\mathbf{1 9 9 9}$ & $\mathbf{2 0 0 0}$ & $\mathbf{2 0 0 1}$ \\
\hline Life & 46,6 & 47,3 & 49,8 & 52,4 & 54,0 & 57,5 & 60,7 & 57,7 \\
\hline $\begin{array}{l}\text { Non- } \\
\text { life }\end{array}$ & 53,3 & 52,6 & 50,1 & 47,5 & 46,0 & 42,4 & 39,2 & 42,3 \\
\hline
\end{tabular}

Source: [15]

Table 7. Gross premium in EU-15 countries, in years 1994-2001, in mln USD, previous year $=100$

\begin{tabular}{|l|c|c|c|c|c|c|c|c|}
\hline \multicolumn{1}{|c|}{ Year } & $\mathbf{1 9 9 4}$ & $\mathbf{1 9 9 5}$ & $\mathbf{1 9 9 6}$ & $\mathbf{1 9 9 7}$ & $\mathbf{1 9 9 8}$ & $\mathbf{1 9 9 9}$ & $\mathbf{2 0 0 0}$ & $\mathbf{2 0 0 1}$ \\
\hline EU-15 & 582578 & 666299 & 694017 & 677010 & 708365 & 769166 & 793163 & 767756 \\
\hline Dynamics & & 114,4 & 104,2 & 97,5 & 104,6 & 108,6 & 100,0 & 102,9 \\
\hline Poland & 1824 & 2302 & 3038 & 3757 & 4464 & 4663 & 4795 & 5151 \\
\hline Dynamics & \multicolumn{2}{|l|}{126,2} & 132,0 & 123,7 & 118,8 & 104,5 & 117,7 & 111,2 \\
\hline & & 1999 & 2000 & 2001 & 2002 & 2003 \\
\hline Lithuania & \multicolumn{2}{l|}{ In mln litas } & & 439,3 & 437,1 & 477,7 & 786,6 & 833,7 \\
\hline Dynamics & \multicolumn{2}{l}{} & & & 99,5 & 109,3 & 164,7 & 106,0 \\
\hline
\end{tabular}

Source: [7] and [15] 
As appears in Table 9, the structure of premiums in division into life and non-life sectors is different from the average value in EU and the tendencies presented in Table 8. In Poland predominates non-life sector, though in the last 10 years it has been systematically decreasing (also visible in years 2002-2003). Thus the changes are directed towards the tendencies occurring on the EU-15 market (with a, at least, 10-year-delay). Concerning insurance market in

Table 9. Structure of premiums (life and non-life) in Poland and Lithuania, in 2002-2003, life and non-life sectors

\begin{tabular}{|l|l|c|c|}
\hline \multicolumn{2}{|c|}{ Year } & $\mathbf{2 0 0 2}$ & $\mathbf{2 0 0 3}$ \\
\hline \multirow{2}{*}{ Poland } & Life & 42,76 & 45,11 \\
\cline { 2 - 4 } & Non-life & 57,24 & 54,89 \\
\hline \multirow{2}{*}{ Lithuania } & Life & 80,82 & 74,45 \\
\cline { 2 - 4 } & Non-life & 19,18 & 25,55 \\
\hline
\end{tabular}

Source: [15] and [16]

Table 10. Structure of premiums in selected classes of non-life insurance, Poland, Lithuania and selected countries of EU-15, in percentage

\begin{tabular}{|c|c|c|c|c|c|}
\hline \multirow{2}{*}{$\begin{array}{l}\text { Insu- } \\
\text { rance } \\
\text { classes }\end{array}$} & \multicolumn{5}{|c|}{ Countries } \\
\hline & $\mathbf{U K}^{\wedge}$ & $\begin{array}{c}\text { Germa- } \\
\text { ny }{ }^{\wedge}\end{array}$ & $\begin{array}{c}\text { France } \\
\wedge @\end{array}$ & Poland\# & $\begin{array}{l}\text { Lithu- } \\
\text { ania* }\end{array}$ \\
\hline $\begin{array}{l}\text { Motor } \\
\text { vehicle }\end{array}$ & 27 & 19 & 14 & 65 & 57 \\
\hline $\begin{array}{l}\text { Trans- } \\
\text { port }\end{array}$ & 10 & 5 & 1 & 1 & - \\
\hline $\begin{array}{l}\text { Fire \& } \\
\text { other } \\
\text { property } \\
\text { damages }\end{array}$ & 20 & 24 & 10 & 19 & 17 \\
\hline $\begin{array}{l}\text { Pecunia- } \\
\text { ry loss }\end{array}$ & 10 & 3 & 1 & 4 & 7 \\
\hline $\begin{array}{l}\text { General } \\
\text { liability }\end{array}$ & 10 & 10 & 2 & 4 & 4 \\
\hline $\begin{array}{l}\text { Accide- } \\
\text { nt and } \\
\text { sickness }\end{array}$ & 10 & 26 & 8 & 6 & 4 \\
\hline $\begin{array}{l}\text { Average } \\
\text { share in } \\
\text { EU-15 }\end{array}$ & 31 & 21 & 16 & & \\
\hline
\end{tabular}

Source: own calculation based on [17], [15] and [16].

NOTES: ^ Average data, 1994-2001 years

(a) Data for direct gross premium

\# Data 2003

* Data 2002

Table 11. Potential competition in a selected country, 2001
Lithuania, the situation is different. Definitely, life sector predominates. The changes are also directed towards the ones nominated by the European market. In the last years, the disproportion between the sectors decreased. In this regard, the markets will still undergo changes.

The next criterion of the analysis is the structure of the sales of individual insurance group. Concerning the available data, it will include non-life sector of selected EU countries only (Great Britain, Germany and France), which play the crucial part, owning totally $68 \%$ shares in insurance sales in the 'old' Union, and of Poland and Lithuania. The basic data is presented in Table 10 .

The data in Table 10 shows considerable diversity among individual insurance groups that can be noticed for the researched countries and three EU-15 countries. It is especially visible in case of motor vehicle insurance, which holds $50 \%$ of the total non-life insurance in Poland and Lithuania. The second is fire and other damages insurance. In reference to the EU-15 countries, usual vehicle insurance predominates, although its share in the total market is considerably smaller. In addition, other types of insurance are divided more proportionally (especially in the UK). The market of the researched countries should therefore still undergo the transformations connected with the expenses on different insurance types. It is linked with the changes of attitudes and consciousness of the insured population and other general factors.

The final comparison shall be the assessment of potential competition in the researched countries. Because of the lack of comparative data, competition in insurance market will only be assessed in reference to the insurers and population number, as presented in Table 11.

The data in Table 11 shows that the number of insurers functioning in the researched countries is significantly larger than in Poland and Lithuania. It proves that there is much bigger choice to be done by the citizens of these countries. Simultaneously, such a large number causes not all of the subjects to be known and recognised. In reference to the countries analysed in the paper, the insurer number is considerably smaller. An interesting comparison would be here the calculation of the ratio of number of a country's population to one insurer. Here, Poland is the only country of such a low potential competition: more than a million citizens in each sector, or approx 500000 citizens in the whole market to one insurer. It is much above the average market quantity in other countries, between 115 and 160 thousand people. In this reference, Lithuania is similar to economi-

\begin{tabular}{|l|c|c|c|c|c|c|c|}
\hline \multirow{2}{*}{ Country } & \multirow{2}{*}{$\begin{array}{c}\text { Population } \\
\text { (in mIn) }\end{array}$} & \multicolumn{3}{c|}{ Number of insurers } & \multicolumn{3}{c|}{ Population/ Number of insurers } \\
\cline { 3 - 8 } & 59,5 & Life & Non-life & Total & Life & Non-life & Total \\
\hline France & 85 & 291 & 376 & 700000 & 204467 & 158245 \\
\hline Germany & 82,5 & 301 & 309 & 610 & 274086 & 266990 & 135246 \\
\hline UK & 59,6 & 196 & 318 & 514 & 304082 & 187421 & 115953 \\
\hline Poland & 38,6 & 36 & 35 & 71 & 1072222 & 1102857 & 543662 \\
\hline Lithuania & 3,5 & 9 & 22 & 31 & 388889 & 159091 & 112903 \\
\hline
\end{tabular}

Source: own calculation based on [15], [16], [17] and [18] 
cally developed countries, which is the result of a smaller population number, at relatively small number of insurers.

\section{Conclusion}

Market maturity dealt with a long-term stabilisation in reference to perfect competition has been the basis of the assessment of the two insurance markets: Polish and Lithuanian. The reference was the data derived from the developedmature markets of the EU, referred to as the 'old' 15. The comparison concludes that both researched markets are not mature yet. They should still be treated as 'emerging markets'. It results from a few features: in the previous years they have been developing much faster than a competitive market, measured in change dynamics of gross premiums. Simultaneously, the two basic indicators of insurance market connected with the state of economy: density and penetration significantly differ from generally accepted standards. The assessment in reference to the division of insurance market into two sectors: life and non-life appears similarly. In the analysed period in the EU-15, there was a change of the structure of the dominant part from non-life to life ones. Poland is still the country where nonlife predominates, while in Lithuania life ones do. However, some changes towards the European average are noticeable. The dominant feature of Polish and Lithuanian insurance markets is the predominance of motor vehicle insurance over other sectors, while in the assessed European countries the structure is much more leveled. Finally, the potential competition available for households and enterprises on insurance market is much larger than in both researched countries. In reference of the population number to the insurer number, only Poland differs significantly from the standard.

The calculations presented in the paper have been done on the basis of available statistic data. Its limited scope caused that not all the comparisons could have been done. It concerns, for instance, the competitive structure of markets (concentration) as well as the structure of life sector of the market. The calculation based on average quantities is also disadvantageous because of presenting the tendencies without considering density.

It is clearly noticeable in case of the market division into life and non-life sectors. In Ireland, for instance, almost $70 \%$ of all insurance sold is life, while in Germany it is only $40 \%$. In addition, calculation based on weight average, with the weight of individual state markets shares in the total sales market of the European Union (15). Moreover, tradition of insurance of the populations and their in- surance consciousness, forming both the need for buying insurance products and actual purchases, were not considered. However, the carried out analysis was to conclude whether Polish and Lithuanian markets aim at 'standard' determined by the developed world countries. The changes observed on both these markets do confirm the hypothesis.

\section{References}

1. HICKS, J. R. Theory of economic history. Torun. Wydawnictwo Adam Marszałek, 2000 (in Polish).

2. HOLT, D.; QUELCH, J.; TAYLOR, E. How global brands compete. Harvard Business Review, Sept 2004.

3. GWIAZDA, A. Globalisation and regionalisation of global economy. Toruń: Wydawnictwo Adam Marszałek, 2000 (in Polish).

4. GALBRAITH, J. K. Monopoly power and price rigidities. The Quarterly Journal of Economics, 1936, Vol 50, No 3.

5. DORFMAN, M. S.; ENNSFELLNER, K. C. The comming of private insurance to a former planned economy: The Case of Slovenia, II F Occasional Papers No 2, Washington, 1998.

6. SCHERER, F. M.; ROSS, D. Industrial market structure and economic performance, $3^{\text {rd }}$ ed, Houghton Miffin Company, Boston, 1990.

7. Insurance Statistical Yearbook 1994-2001, OECD, 2003.

8. Sigma no 1, 2001, World financial centres: New horizons in insurance and banking, Swiss Re, Zurich.

9. SANGOWSKI, T. Polish insurance market - situational analysis and future directions. In Insurance in the Market Economy, ed T. Sangowski, Branta, Bydgoszcz, 2002 (in Polish).

10. SUŁKOWSKA, W. (ed). Barriers in developing the Polish insurance market, ed Zamykacze, Kraków, 2000 (in Polish).

11. HANDSCHKE, J. (ed). Internet and insurance contracts in Poland. Report, Dept of Insurance at the Academy of Economics in Poznan, 2004 (in Polish).

12. PERENC, J. (ed). The market of insurance services. Publishing House of the University of Szczecin, Szczecin, 2004.

13. Statistical Yearbook of the Republic of Poland, 2004.

14. Sigma no $8 / 2003$, World insurance 2002 : high premium growth in non-life insurance.

15. Overview 2003, Insurance Supervisory Commission of the Republic of Lithuania, 2004.

16. Quarterly Bulletin. Insurance Market 3/2004, KNUiFE.

17. Insurance and Pension Funds Supervisory Committee, Poland. Available from Internet: <www.knuife.gov.pl>

18. State Insurance Supervisory Authority, Lithuania. Available from Internet: <www.vdpt.lt>

\section{DRAUDIMO RINKOS BRANDA: LYGINAMOJI LENKIJOS IR LIETUVOS ANALIZE்}

\section{T. Bernat, D. Grundey}

Santrauka

Straipsnyje nagrinèjama draudimo rinkos tematika, ypač aktualūs reiškiniai šiai rinkai pasiekus brandos stadiją. Autoriai akcentuoja, jog išsivysčiusiose pasaulio šalyse rinkos ekonomika - jau seniai vyraujantis rinkos svertas. Tačiau naujosios Europos Sajungos (ES) šalys, įskaitant Lenkiją ir Lietuva, perejo daugelį rinkos transformacijų etapų, siekdamos igyvendinti rinkos ekonomikos principus ir 
drąsiai žvelgdamos į savo „eksperimentu“ “ rezultatus. Šio straipsnio tikslas - Lenkijos ir Lietuvos draudimo rinkų situacijos vertinimas ES-15 šalių kontekste. Straipsnyje pagrindžiama hipotezė, jog tirtose šalyse (Lenkijoje ir Lietuvoje), kurios perejo ekonomikos sistemos transformacijas, draudimo rinkos funkcionavimas modeliuojamas pagal išsivysčiusių šalių modelius, kurie jau seniai jose funkcionuoja ir yra ekonomiškai naudingi.

Reikšminiai žodžiai: draudimo rinka, rinkos branda, konkurencija, Lenkija, Lietuva.

Tomasz BERNAT. Doctor. Lecturer at Dept of Microeconomics, Faculty of Economics and Management, University of Szczecin (Poland). Working on his Habilitation thesis, related to insurance market issues. Co-coordinator of $6^{\text {th }} \mathrm{FP}$ MCA (ToK) project "Competitiveness of labour market and its entities" (2005-2009). Author of over 20 international publications and editor/co-editor of several books in Polish and English. Fields of scientific interests include insurance market, microeconomics, human resources, labour market competitiveness.

Dainora GRUNDEY. Dr, Assoc Prof. Dept of Business Economics and Management, Kaunas Faculty of Humanities, Vilnius University (Lithuania) and Vice-Dean for Scientific Research and International Relations at the Faculty. Deputy Editor-in-Chief of "Transformations in Business \& Economics" (ISI rating since 2005) (www.transformations.khf.vu.lt) and Editor-in-Chief of IJORTISS (http:// ijortiss.vukhf.lt). Member of editorial boards of several international scientific journals. Participant of several international and European projects. Coordinator of the INYRSS network (http://inyrss.vukhf.lt). The author of numerous scientific articles and book chapters (over 140) on marketing, international business and marketing, consumer behaviour, cross-cultural marketing, applications of sustainability in the spheres of marketing, services and the education system. 